\title{
Studies on the Synthesis of Condensed Heterocyclic Isoquinolone Derivatives. I. Studies on the Synthesis and Pharmacology of Thiazino, Oxazino and Pyrimido Isoquinolones
}

\author{
Kazuo Kubo, Noriki Ito, Yasuo Isomura, Isao Sozu, \\ Hiroshige Homma, and Masuo Murakami \\ Central Research Laboratories, Yamanouchi Pharmaceutical Co., Ltd.1)
}

(Received March 31, 1979)

\begin{abstract}
5-Oxo-1,2,3,5-tetrahydro-5H-imidazo[1,2-b]isoquinoline (IIa) and related compounds were synthesized from homophthalic acid and an aliphatic 1,2- or 1,3-diamine. In addition, homophthalic acids or 0 -carboxyphenylmalonic acid diesters were allowed to react with an aliphatic 1,2- or 1,3-aminoalcohol or aminothiol with heating in the presence of $p$-toluenesulfonic acid, yielding a series of oxazolo- or oxazino-isoquinolones (VI) or thiazolo- or thiazino-isoquinolones (IV). Oxidation of IV gave the corresponding sulfoxides (VII) and sulfones (VIII). Treatment of o-cyanomethylbenzenesulfonyl chloride with an $\mathrm{N}$-alkyl 1,2- or 1,3-diamine gave $\mathrm{N}$-alkyl-imidazo- or pyrimido-benzothiazine5,5-dioxide (XI).

The compounds thus prepared were evaluated for their anti-inflammatory effect in rats, using the carrageenin paw edema method, and some of the condensed heterocyclic isoquinolone derivatives were found to exhibit strong anti-inflammatory activity. These compounds were also examined for analgesic activity in terms of the inhibition of acetic acid induced writhing. Compound VIIIk showed stronger anti-inflammatory activity than phenylbutazone, as well as analgesic activity comparable to that of aminopyrine, and had very low toxicity.
\end{abstract}

Keywords_anti-inflammatory activity; analgesic activity; thiazolo[3,2-b]isoquinolone; thiazino[3,2-b]isoquinolone; imidazo[3,2-b]isoquinolone; oxazolo[3,2- $b]$ isoquinolone; oxazino[3,2-b]isoquinolone; imidazo $[3,2-b](1,2)$ benzothiazine-5,5-dioxide; structure- activity relationship

In previous papers, ${ }^{2)}$ we reported on the synthesis and pharmacological activities of a series of compounds having pyridone structures. In the present work, a series of condensed heterocyclic isoquinolone derivatives was synthesized and the pharmacology of these compounds was investigated. It has been found that thiazino isoquinolones show strong antiinflammatory and analgesic activities, and have very low toxicity.

\section{Synthesis}

5-Oxo-1,2,3,5-tetrahydro-5H-imidazo[1,2-b]isoquinolines $\left.\mathrm{IIa},{ }^{3 a}\right) \mathrm{b}$ and c were synthesized by the reaction of homophthalic acid (I) with aliphatic 1,2- or 1,3-diamine in 0 -dichloro benzene with heating according to the method of Nagarajan et al..$^{35)}$

5-Oxo-2,3-dihydro-5H-thiazolo[3,2-b] isoquinoline (IVa) ${ }^{4)}$ was prepared from I by allowing it to react with 2 -aminoethanethiol in the presence of sodium acetate in boiling acetic acid.

1) Location: 1-1-8, Azusawa, Itabashi-ku, Tokyo.

2) Part I: K. Kubo, N. Ito, Y. Isomura, I. Sozu, H. Homma, H. Arima, and M. Murakami, Yakugaku Zasshi, 99, 588 (1979); Part II: K. Kubo, N. Ito, Y. Isomura, I. Sozu, H. Homma, and M. Murakami, Chem. Pharm. Bull. (Tokyo), 27, 1207 (1979); Part III: K. Kubo, N. Ito, Y. Isomura, I. Sizu, H. Homma, and M. Murakami, Yakugaku Zasshi, 99, 788 (1979); Part IV: K. Kubo, N. Ito, Y. Isomura, I. Sozu, H. Homma, and M. Murakami, Yakugaku Zasshi, 99, 880 (1979).

3) a) E. Schefczik, Ann. Chem., 729, 83 (1969); b) K. Nagarajan, V.R. Rao, and R.K. Shah, J. Indian Chem. Soc., 663 (1970).

4) E. Schefczik, Ger. Patent 1960376 (1971) [C.A., 75, 63774z (1971)]. 
When treated with 3-aminopropanethiol, however, I afforded 6-oxo-3,4-dihydro- $2 \mathrm{H}, 6 \mathrm{H}$-thiazino[3,2-b]isoquinoline (IVf) and $\mathrm{N}$ - $\gamma$-mercaptopropylhomophthalimide (III) in $18.5 \%$ and $32 \%$ yields, respectively. Compound III showed the parent ion at $m / e$ 235 in the mass spectrum (MS) and one proton signal due to a thiol group (1.5 ppm, $\mathrm{t})$, three methylene group signals $(1.96 \mathrm{ppm}, \mathrm{m}, 2.56 \mathrm{ppm}, \mathrm{t}$ of $\mathrm{t}, 4.10 \mathrm{ppm}, \mathrm{t})$ and one methylene group signal at the 4-position (4.04 ppm, s) in the nuclear magnetic resonance (NMR) spectrum. These spectral data support the structure III. The MS $\left(m / e: 217 \mathrm{M}^{+}\right)$and microanalysis results for IVf indicated the molecular formula $\mathrm{C}_{12} \mathrm{H}_{11}$ NOS. The NMR spectrum of IVf showed three methylene group signals due to the thiazino ring $(2.1-2.4 \mathrm{ppm}, 3.1 \mathrm{ppm}, 4.2 \mathrm{ppm})$, one olefinic proton signal at the 11 -position $(6.5 \mathrm{ppm})$ and one aromatic proton signal $(8.3-8.5$ $\mathrm{ppm}$ ) shifted to lower field by the anisotropy effect of a carbonyl group. These data are consistent with the structure IVf.

When I was allowed to react with 3 -aminopropanethiol in 0 -dichlorobenzene at 140 $150^{\circ}$, with removal of water by azeotropic distillation, III was obtained in $76 \%$ yield. Treatment of III with $p$-toluenesulfonic acid in $o$-dichlorobenzene at $90-120^{\circ}$ afforded IVf in $68 \%$ yield.

When oxidized with hydrogenperoxide in acetic acid, IVf gave the corresponding sulfoxide (VIIe) at room temperature and the corresponding sulfone (VIIId) at $70-80^{\circ}$.

Schefczik ${ }^{4)}$ prepared N-hydroxyethylhomophthalimide (V) from I by allowing it to react with 2-aminoethanol in the presence of acetic acid in boiling xylene.

When $I$ was allowed to react with 2 -aminoethanol in the presence of $p$-toluenesulfonic acid as described for the synthesis of IVf, however, 5-oxo-2,3-dihydro-5H-oxazolo[3,2-b]isoquinoline (VIa) was obtained in good yield. The structure of VIa was determined on the basis of the microanalysis data and the NMR spectrum, which was similar to that of IVa. A similar reaction of I and 3-aminopropanol gave VIc.

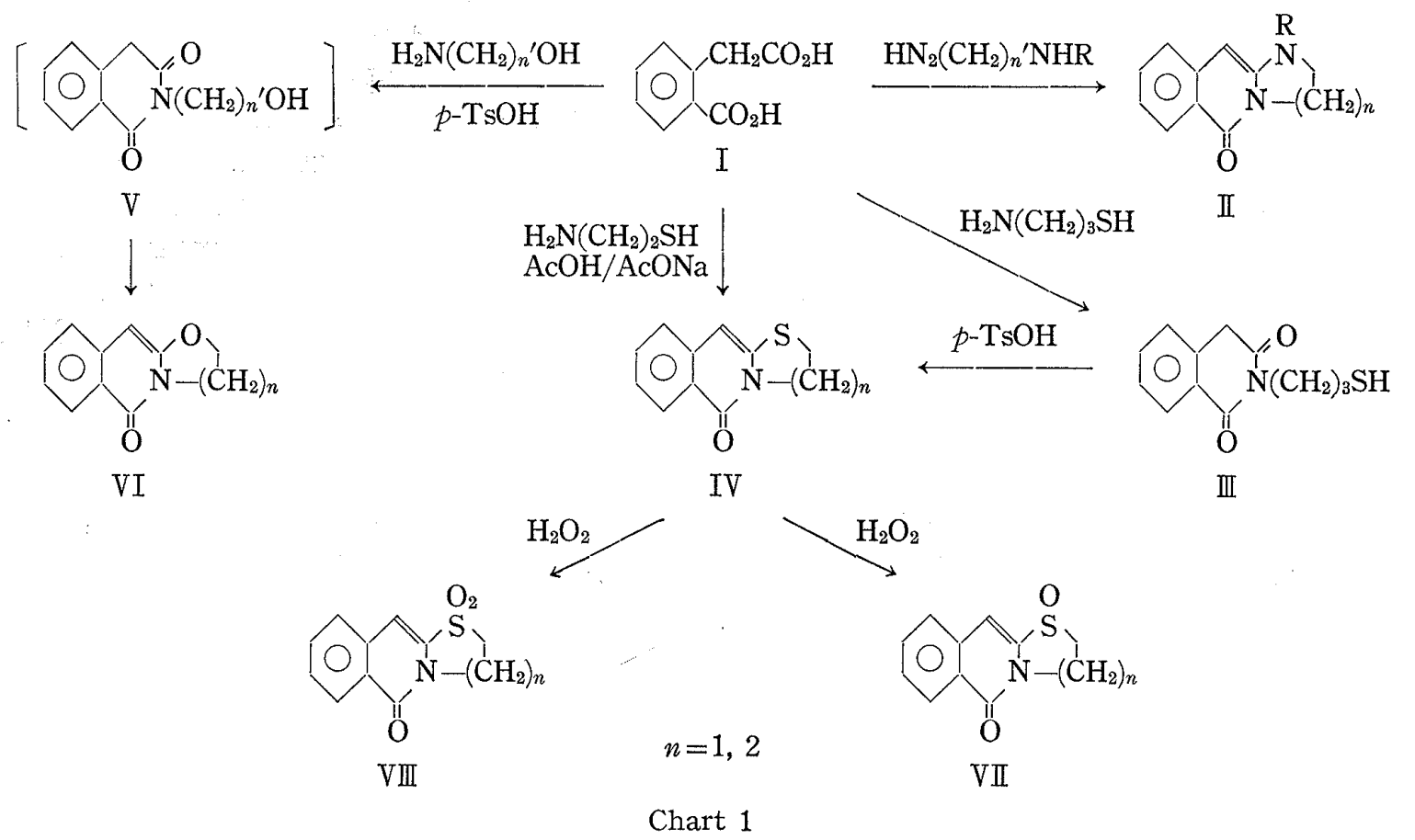

N-Alkyl-2,3-dihydro-1H-imidazo[1,2-b](1,2) benzothiazine-5,5-dioxides (XI) (compounds related to II, having a sulfoneamide bond instead of the amide bond of II) were also synthesized. Thus, treatment of $o$-chlorosulfonyl benzylcyanide (IX) $)^{5}$ with an excess of $\mathrm{N}$-ethylethylenediamine at $-15^{\circ}$ gave XIa, mp $123-124^{\circ}$, in $35 \%$ vield. On the basis of the MS (m/e: 250, M+) and microanalysis data, XIa was assigned the formula $\mathrm{C}_{12} \mathrm{H}_{14} \mathrm{~N}_{2} \mathrm{O}_{2} \mathrm{~S}$. The infrared (IR) spectrum showed an absorption band of the sulfoneamide group at 1310 
$\mathrm{cm}^{-1}$ and the NMR spectrum showed one proton signal at the 10-position (5.1 ppm), one aromatic proton signal at the 5-position $(7.7-7.8 \mathrm{ppm})$ and two methylene group signals (3.2-3.5 ppm, t, 3.8-4.0 ppm). Thus XIa was concluded to be 1-ethyl-2,3-dihydro-1Himidazo[3,2-b](1,2)benzothiazine-5,5-dioxide. When IX was treated with one molar equivalent of N-ethylethylenediamine, o-(N-ethylaminoethylaminosulfonyl)benzylcyanide (Xa) was obtained. The structure of Xa was evident from the microanalysis data, MS (m/e: 267, $\left.\mathrm{M}^{+}\right)$, the presence of an absorption band of the cyano group $\left(2250 \mathrm{~cm}^{-1}\right)$ in the IR spectrum and the presence of a benzyl proton signal $(4.48 \mathrm{ppm})$ in the NMR spectrum. On treatment with triethylamine in methanol, Xa was converted to XIa

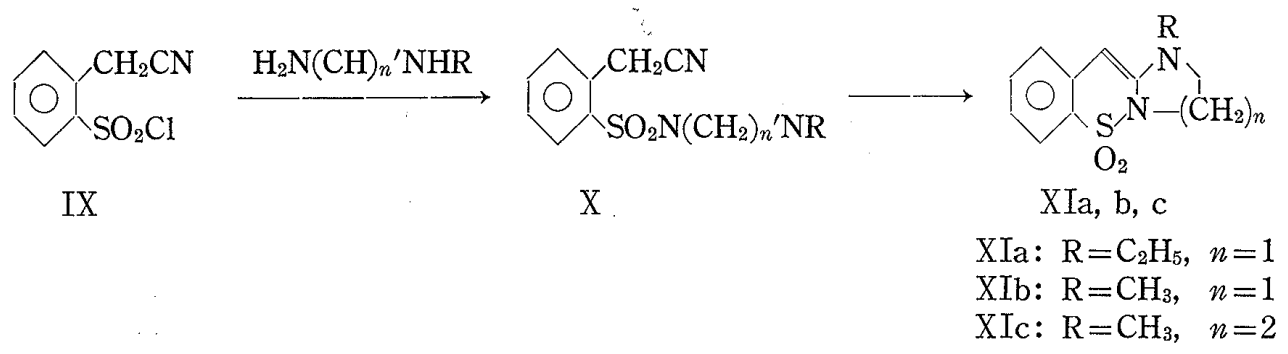

Chart 2

The pharmacological activities of the compounds thus prepared were studied. IVf VIIe, and VIIId showed strong anti-inflammatory and analgesic activities, and had low toxicity. In order to obtain more potent compounds, some modifications of these compounds were carried out. Homophthalic acids having alkyl, benzyl or phenyl groups at the $\alpha$-position were prepared to introduce a substituent at the 4-position of the isoquinolone moiety. Homophthalic acids having nitro, amino, alkyl, alkoxy and halogen groups on the benzene ring were also synthesized. These homophthalic acid derivatives were heated with an aliphatic 1,2- or 1,3-aminothiol in o-dichlorobenzene, removing water by azeotropic distillation, and then $p$-toluenesulfonic acid was added to the reaction mixture to give a series of thiazino or thiazolo isoquinolone derivatives (IV). Oxidation of the compounds thus obtained with hydrogenperoxide gave the corresponding sulfoxides (VII) and sulfones (VIII).

Compounds $I V_{\mathrm{W}}-\mathrm{y}$ were also prepared by the reaction of $o$-carboxyphenylmalonic acid diester derivatives ${ }^{6)}$ with an aliphatic 1,2 - or 1,3-aminothiol, followed by deethoxycarbonylation. Data for compounds II, IV, VII and VIII are listed in Table I and data for XI are listed in Table II.

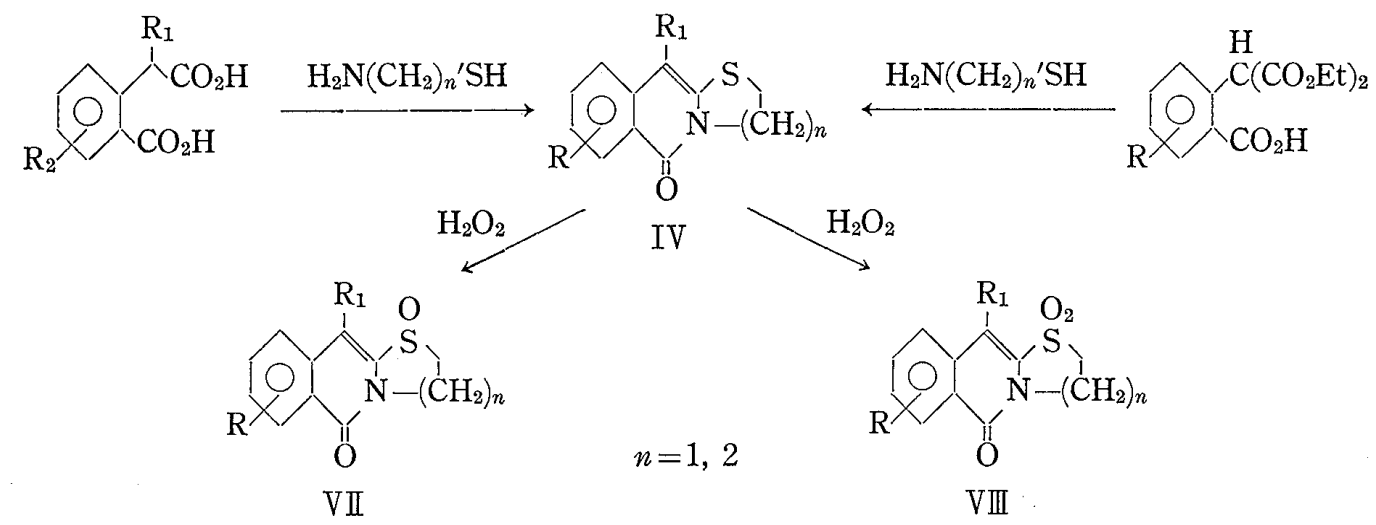

Chart 3

5) E. Sianesi, R. Redaelli, M. Bertani, and P. Da Re, Chem. Ber., 103, 1992 (1970).

6) A. Brugginik and A. Mekillor, Tetrahedron, 3, 2697 (1975). 

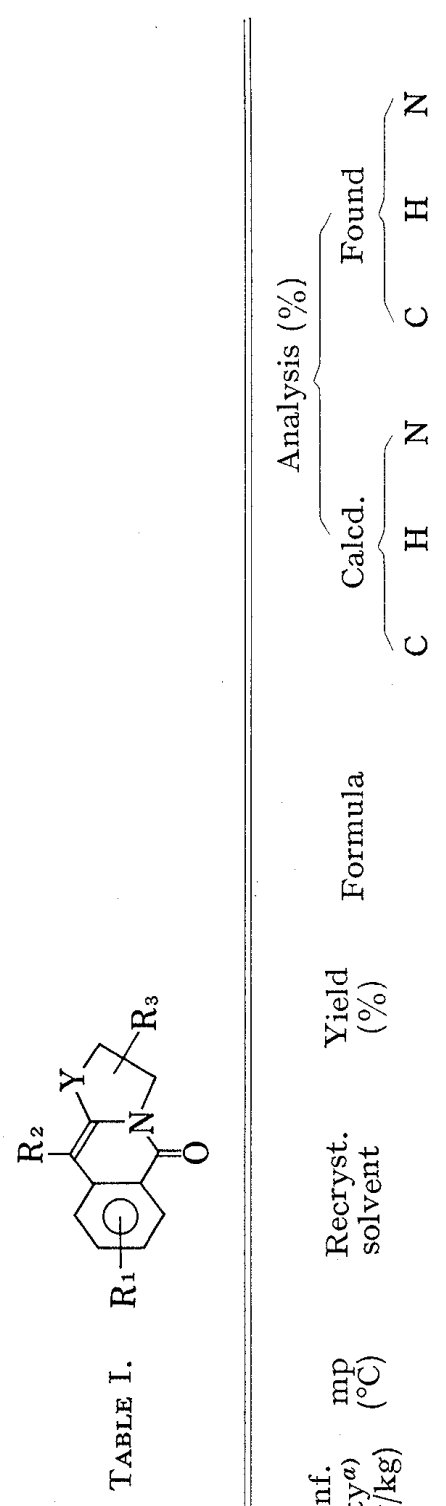

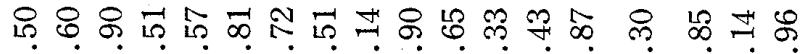
过 00 is ภํำ

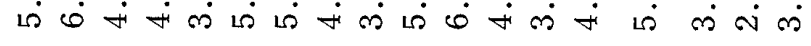

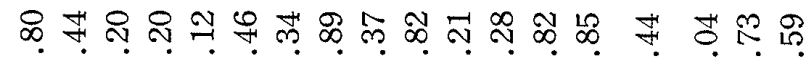

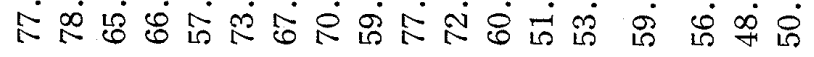

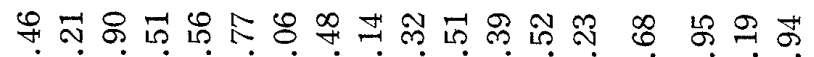

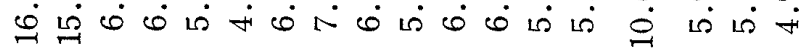

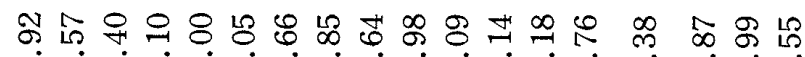

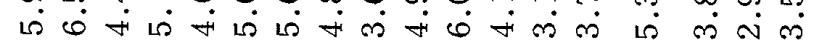
ㄴํำ 우 숭 8 它

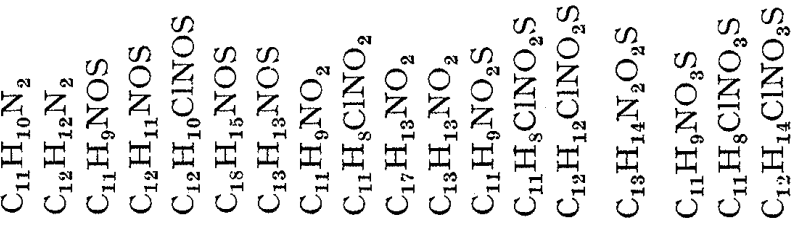

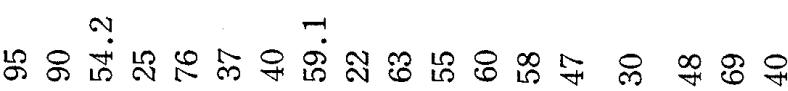
票 空过导 :

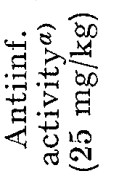

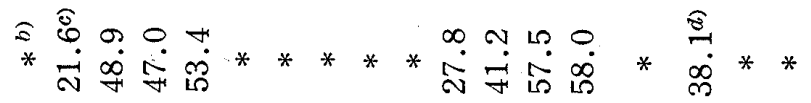
Æ

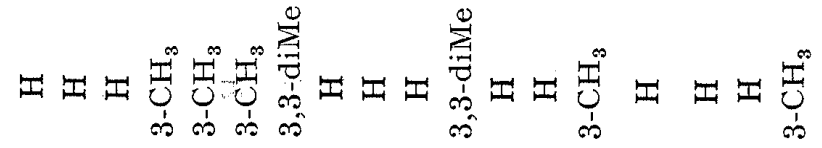

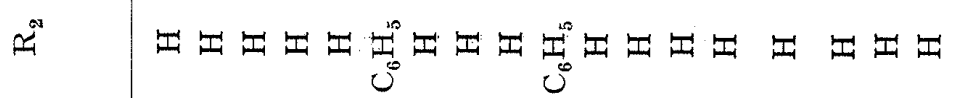

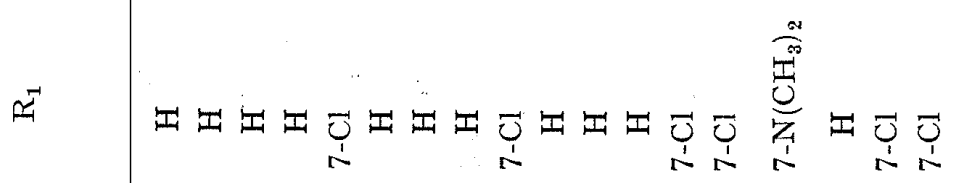

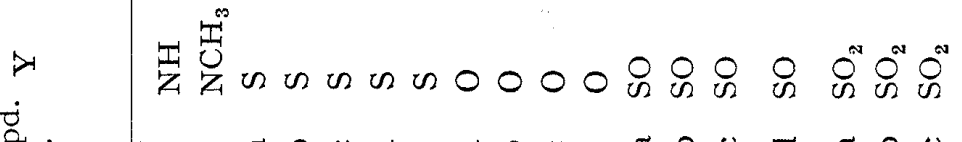

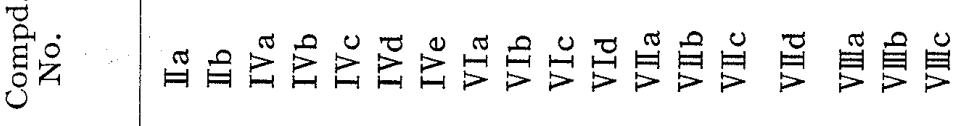




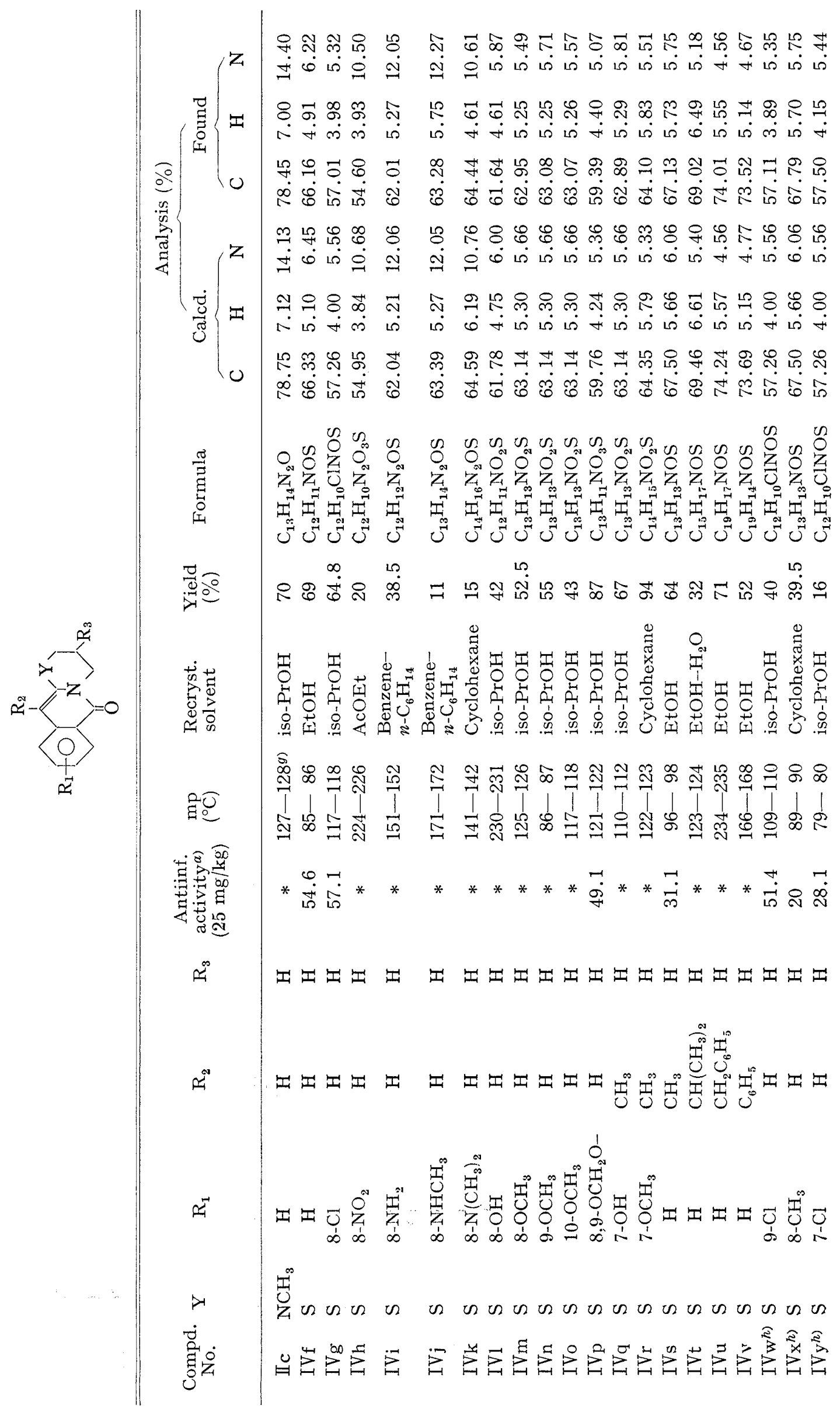




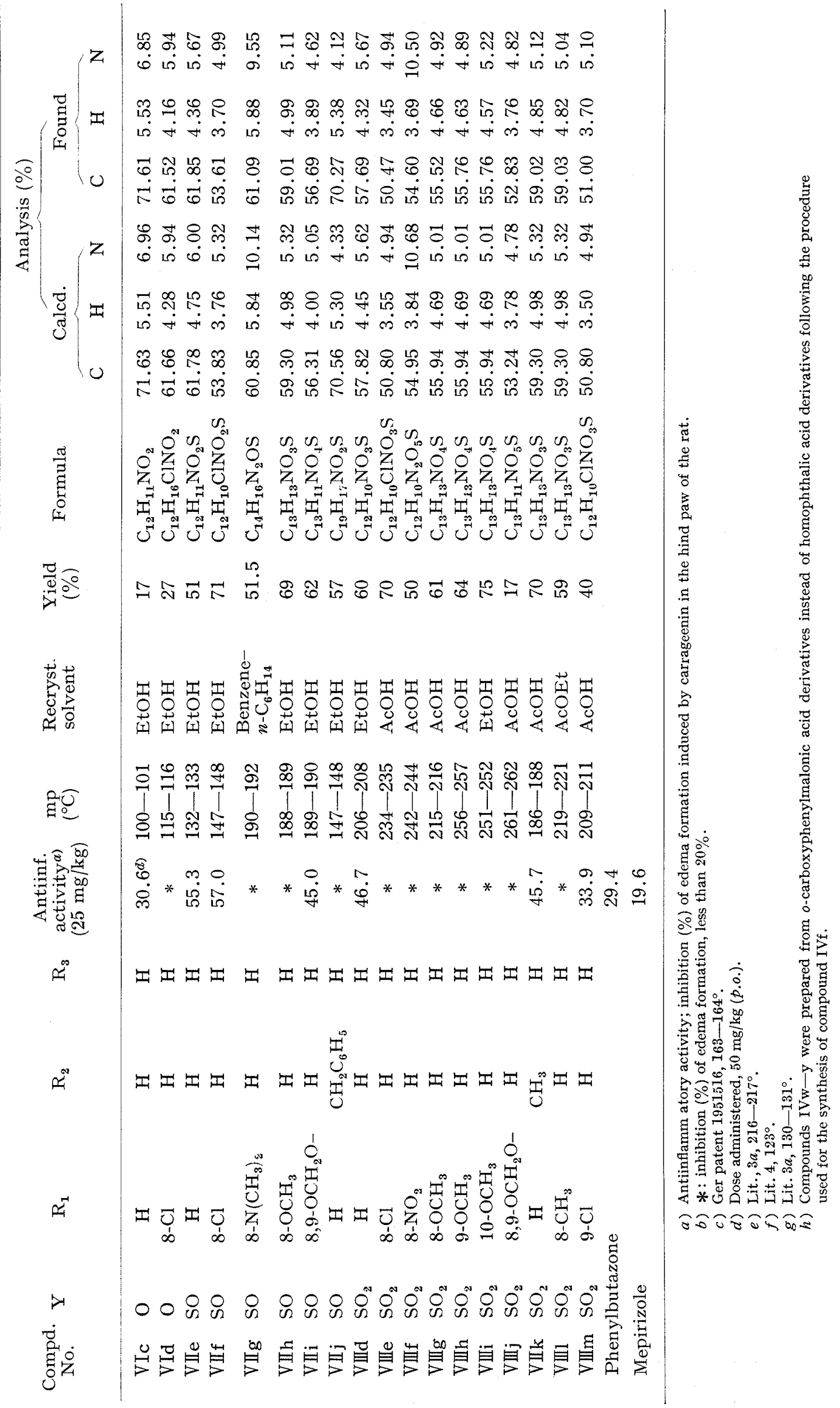


<smiles></smiles><smiles>[R10]C1C(=O)c2ccccc2C=C1Cl</smiles>

XII

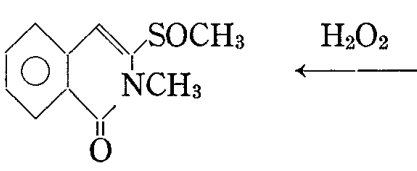

XIV

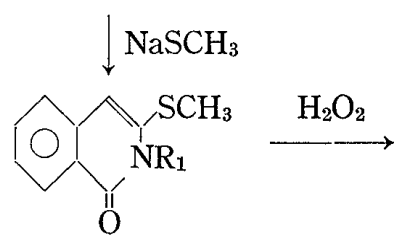

XIIIa, b, c

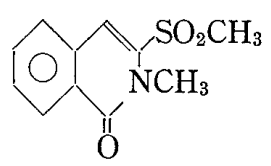

$\mathrm{XV}$

XIIIa: $\mathrm{R}_{\mathbf{1}}=\mathrm{CH}_{3}$

XIIb: $\mathrm{R}_{1}=\mathrm{C}_{2} \mathrm{H}_{5}$

XIIlc: $\mathrm{R}_{1}=\mathrm{CH}_{2} \mathrm{C}_{6} \mathrm{H}_{5}$

Chart 4

TABLE II.

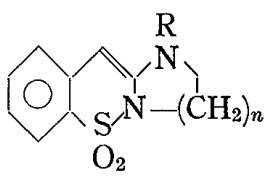

\begin{tabular}{|c|c|c|c|c|c|c|c|c|c|c|}
\hline \multirow{2}{*}{$\begin{array}{l}\text { Compd. } \\
\text { No. }\end{array}$} & \multirow[t]{2}{*}{$\mathrm{R}$} & \multirow{2}{*}{$n$} & \multirow{2}{*}{$\begin{array}{l}\text { Antiinf. } \\
\text { activity } \\
(100 \mathrm{mg} / \mathrm{kg})\end{array}$} & \multirow{2}{*}{$\operatorname{mp}_{\left({ }^{\circ} \mathrm{C}\right)}$} & \multirow{2}{*}{$\begin{array}{l}\text { Recryst. } \\
\text { solvent }\end{array}$} & \multirow{2}{*}{$\begin{array}{l}\text { Yield } \\
(\%)\end{array}$} & \multirow[t]{2}{*}{ Formula } & \multicolumn{3}{|c|}{$\begin{array}{l}\text { Analysis (\%) } \\
\text { Calcd. } \\
\text { (Found) }\end{array}$} \\
\hline & & & & & & & & C & $\mathrm{H}$ & $N$ \\
\hline XIa & $\mathrm{C}_{2} \mathrm{H}_{5}$ & 1 & 42.0 & $123-124$ & $\mathrm{MeOH}$ & 35 & $\mathrm{C}_{12} \mathrm{H}_{14} \mathrm{~N}_{2} \mathrm{O}_{2} \mathrm{~S}$ & $\begin{array}{r}57.53 \\
(57.34\end{array}$ & $\begin{array}{l}5.64 \\
5.66\end{array}$ & $\begin{array}{l}11.19 \\
11.08)\end{array}$ \\
\hline XIb & $\mathrm{CH}_{3}$ & 1 & 28.8 & $157-158$ & $\mathrm{MeOH}$ & 30 & $\mathrm{C}_{11} \mathrm{H}_{12} \mathrm{~N}_{2} \mathrm{O}_{2} \mathrm{~S}$ & $\begin{array}{r}55.93 \\
(55.64\end{array}$ & $\begin{array}{l}5.08 \\
5.02\end{array}$ & $\begin{array}{l}11.86 \\
11.90)\end{array}$ \\
\hline XIc & $\mathrm{CH}_{3}$ & 2 & 24.1 & $160-161$ & $\mathrm{MeOH}$ & 34.4 & $\mathrm{C}_{12} \mathrm{H}_{1 \mathrm{i}} \mathrm{N}_{2} \mathrm{O}_{2} \mathrm{~S}$ & $\begin{array}{r}57.58 \\
(57.61\end{array}$ & $\begin{array}{l}5.64 \\
5.65\end{array}$ & $\begin{array}{l}11.19 \\
11.30)\end{array}$ \\
\hline \multicolumn{3}{|c|}{ Phenylbutazone } & 51.2 & & & & & & & \\
\hline
\end{tabular}

a) Antiinflammatory activity; inhibition (\%) of edema formation induced by carrageenin in the hind paw of the rat.

TABLE III.

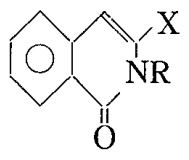

\begin{tabular}{|c|c|c|c|c|c|c|c|c|c|c|}
\hline \multirow[t]{2}{*}{$\begin{array}{l}\text { Compd. } \\
\text { No. }\end{array}$} & \multirow[t]{2}{*}{$\mathrm{X}$} & \multirow[t]{2}{*}{$\mathrm{R}$} & \multirow{2}{*}{$\begin{array}{l}\text { Antiinf. } \\
\text { activity }) \\
(50 \mathrm{mg} / \mathrm{kg})\end{array}$} & \multirow{2}{*}{$\operatorname{mp}_{\left({ }^{\circ} \mathrm{C}\right)}$} & \multirow[t]{2}{*}{$\begin{array}{l}\text { Recryst. } \\
\text { solvent }\end{array}$} & \multirow[t]{2}{*}{$\begin{array}{l}\text { Yield } \\
(\%)\end{array}$} & \multirow[t]{2}{*}{ Formula } & \multicolumn{3}{|c|}{$\begin{array}{c}\text { Analysis (\%) } \\
\text { Calcd. } \\
\text { (Found) }\end{array}$} \\
\hline & & & & & & & & C & $\mathrm{H}$ & $\mathrm{N}$ \\
\hline XIIIa & $\mathrm{SCH}_{3}$ & $\mathrm{CH}_{3}$ & 57.3 & $83-85$ & Cyclohexane & 71 & $\mathrm{C}_{11} \mathrm{H}_{11} \mathrm{NOS}$ & $\begin{array}{r}64.36 \\
(64.49\end{array}$ & $\begin{array}{l}5.40 \\
5.19\end{array}$ & $\begin{array}{l}6.82 \\
6.91)\end{array}$ \\
\hline XIIIb & $\mathrm{SCH}_{2}$ & $\mathrm{C}_{2} \mathrm{H}_{5}$ & 38.5 & $80-82$ & Cyclohexane & 49 & $\mathrm{C}_{12} \mathrm{H}_{13} \mathrm{NOS}$ & $\begin{array}{r}65.42 \\
665.46\end{array}$ & $\begin{array}{l}5.97 \\
5.85\end{array}$ & $\begin{array}{l}6.39 \\
6.45)\end{array}$ \\
\hline XIIIc & $\mathrm{SCH}_{3}$ & $\mathrm{CH}_{2} \mathrm{C}_{6} \mathrm{H}_{5}$ & $* b)$ & $79-80$ & Cyclohexane & 67.6 & $\mathrm{C}_{18} \mathrm{H}_{17} \mathrm{NOS}$ & $\begin{array}{r}73.19 \\
(73.39\end{array}$ & $\begin{array}{l}5.80 \\
5.80\end{array}$ & $\begin{array}{l}4.74 \\
4.38)\end{array}$ \\
\hline XIV & $\mathrm{SOCH}_{3}$ & $\mathrm{CH}_{3}$ & 55.8 & $157-159$ & $\mathrm{MeOH}$ & 65 & $\mathrm{C}_{11} \mathrm{H}_{11} \mathrm{NO}_{2} \mathrm{~S}$ & $\begin{array}{r}59.71 \\
(59.54\end{array}$ & $\begin{array}{l}5.01 \\
4.78\end{array}$ & $\begin{array}{l}6.33 \\
6.51)\end{array}$ \\
\hline XV & $\mathrm{SO}_{2} \mathrm{CH}_{3}$ & $\mathrm{CH}_{3}$ & 50.7 & $179-180$ & EtOH & 52 & $\mathrm{C}_{11} \mathrm{H}_{11} \mathrm{NO}_{3} \mathrm{~S}$ & $\begin{array}{r}55.68 \\
(55.51\end{array}$ & $\begin{array}{l}4.47 \\
4.34\end{array}$ & $\begin{array}{l}5.90 \\
5.79)\end{array}$ \\
\hline Phenyl & butazone & & 44.5 & & & & & & & \\
\hline
\end{tabular}

a) Antiinflammatory activity; inhibition (\%) of edema formation induced by carrageenin in the hind paw of the rat.

b) *: inhibition (\%) of edema formation, less than $20 \%$. 
3-Alkylthio-substituted isoquinolones were also prepared. Reaction of 3-chloroisoquinolone $^{7)}$ with dimethyl sulfate or an alkyl halides in the presence of sodium methoxide gave $\mathrm{N}$-alkyl-3-chloroisoquinolones (XII). On treatment with an alkylthiolate, XII was converted to 3-alkylthio-substituted isoquinolones (XIII). Compound XIIIa was oxidized to the corresponding sulfoxide (XIV) and sulfone (XV). Data for these compounds are listed in Table III.

\section{Pharmacology and Discussion}

\begin{tabular}{|c|c|c|c|c|c|}
\hline $\begin{array}{c}\text { Compd. } \\
\text { No. }\end{array}$ & $\mathrm{R}_{\mathrm{i}}$ & $\mathrm{R}_{2}$ & $n$ & $\mathrm{X}$ & $50 \mathrm{mg} / \mathrm{kg}$ \\
\hline IIb & $\mathrm{H}$ & $\mathrm{H}$ & 1 & $\mathrm{NCH}_{3}$ & 51.5 \\
\hline II & $\mathrm{H}$ & $\mathrm{H}$ & 2 & $\mathrm{NCH}_{3}$ & 50.0 \\
\hline IVa & $\mathrm{H}$ & $\mathrm{H}$ & 1 & $\mathrm{~S}$ & 46.4 \\
\hline IVc & 8-Cl & $\mathrm{H}$ & 1 & $\mathrm{~S}$ & 70.0 \\
\hline IVf & $\mathrm{H}$ & $\mathrm{H}$ & 2 & $\mathrm{~S}$ & 57.8 \\
\hline $\mathrm{IVg}$ & 8-Cl & $\mathrm{H}$ & 2 & $\mathrm{~S}$ & 28.8 \\
\hline $\mathrm{IV}_{\mathrm{s}}$ & H & $\mathrm{CH}_{3}$ & 2 & $\mathrm{~S}$ & 31.6 \\
\hline $\mathrm{I} \mathrm{V}_{\mathrm{w}}$ & $9-\mathrm{Cl}$ & $\mathrm{H}$ & 2 & $\mathrm{~S}$ & 25.0 \\
\hline $\mathrm{VIa}$ & $\mathrm{H}$ & $\mathrm{H}$ & 1 & 0 & 90.7 \\
\hline $\mathrm{VIIa}$ & $\mathrm{H}$ & $\mathrm{H}$ & 1 & SO & 39.7 \\
\hline VIIb & $8-\mathrm{Cl}$ & $\mathrm{H}$ & 1 & SO & 74.3 \\
\hline VIIc & $\mathrm{H}$ & $\mathrm{H}$ & 2 & SO & 58.6 \\
\hline VIIf & $8-\mathrm{Cl}$ & $\mathrm{H}$ & 2 & SO & 61.6 \\
\hline VIII & $\mathrm{H}$ & $\mathrm{H}$ & 2 & $\mathrm{SO}_{2}$ & 14.4 \\
\hline $\mathrm{VIIK}$ & $\mathrm{H}$ & $\mathrm{CH}_{3}$ & 2 & $\mathrm{SO}_{2}$ & 44.4 \\
\hline \multicolumn{2}{|c|}{ Aminopyrine } & & & & 58.1 \\
\hline
\end{tabular}

a) Inhibition (\%) of writhing induced by acetic acid in mice.

The anti-inflammatory activity of these compounds was determined by means of the carrageenin paw edema assay method as described by Winter, et al.8) and was compared with that of phenylbutazone and mepirizole. The tricyclic compounds IVa, f, VIIa, c and VIIId, $\mathrm{k}$ showed stronger activity than phenylbutazone and mepirizole but XIa, $\mathrm{c}$ with a sulfonamide bond instead of the amide bond, showed only weak activity. The activity of alkylthio isoquinolones (XIII-XV) was rather weak compared with those of IVf and VIIId, k. Among the thiazino derivatives having a substituent on the benzene ring, halogen substituted compounds retained the activity, but their oxidation products VIIIb, $\mathrm{c}, \mathrm{m}$ showed markedly decreased activity.

Compounds having a substituent larger than a methyl group at the 11-position of IVf did not show significant activity in our test system. Compounds showing relatively strong anti-inflammatory activity were selected and examined for analgesic activity in terms of the inhibition of writhing induced by acetic acid. ${ }^{9)}$

Most of the compounds showed analgesic activity stronger than that of aminopyrine. These compounds were next tested for acute toxicity in mice (p.o.). The toxicity decreased in the order IV, VI and VIII. Among them, VIIId and VIIIk showed remarkably low

7) G. Simchen and G. Entenman, Angew. Chem. Int. Ed. Engl., 12, 2607 (1975).

8) C.A. Winter, E.A. Risley, and G.W. Nuss, Proc. Soc. Exp. Biol. Med., 111, 544 (1962).

9) R. Kostar, M. Anderson, and E.J. Debbeer, Fed. Proc., 22, 248 (1963). 
toxicities and none of the mice tested died even after the oral administration of $2500 \mathrm{mg} / \mathrm{kg}$. VIIIk showed an $\mathrm{ED}_{50}$ value of $33 \mathrm{mg} / \mathrm{kg}$ in the rat carrageenin paw edema assay method and an $\mathrm{ED}_{50}$ value of $55 \mathrm{mg} / \mathrm{kg}$ in the acetic acid induced writhing assay method. Thus VIIIk was selected for further study, and pharmacological data on this compound will be reported elsewhere.

\section{Experimental ${ }^{10)}$}

6-0xo-3,4-dihydro-2H,6H-1,3-thiazino[3,2-b] isoquinoline (IVf) and $\mathrm{N}-\gamma$-Mercaptopropylhomoph thalimide (III) - A mixture of $3.6 \mathrm{~g}$ of homophthalic acid (I), $3.4 \mathrm{~g}$ of 3-aminopropanethiol hydrobromide and $3.28 \mathrm{~g}$ AcONa in $110 \mathrm{ml}$ of AcOH was refluxed overnight. The solvent was then evaporated off in vacuo and the residue was extracted with $\mathrm{CHCl}_{3}$. The extract was washed with dilute alkali, dried over $\mathrm{MgSO}_{4}$ and concentrated in vacuo. The residue was passed through a column of silica gel and eluted with $\mathrm{CHCl}_{3}$ to give two fractions. The first fraction gave $1.8 \mathrm{~g}$ (yield $32 \%$ ) of yellow oil, III. Anal. Calcd. for $\mathrm{C}_{12} \mathrm{H}_{13} \mathrm{NO}_{2} \mathrm{~S}$ : $\mathrm{C}, 61.25 ; \mathrm{H}, 5.57 ; \mathrm{N}, 5.95$. Found: C, 61.22; H, 5.36; N, 5.84. NMR $\left(\mathrm{CDCl}_{3}\right) \mathrm{ppm}: 1.5(1 \mathrm{H}, \mathrm{t}, J=8 \mathrm{~Hz})$, $1.96(2 \mathrm{H}, \mathrm{m}), 2.56(2 \mathrm{H}, \mathrm{t}$ of $\mathrm{t}, J=7 \mathrm{~Hz}, J=7 \mathrm{~Hz}), 4.10(2 \mathrm{H}, \mathrm{t}, J=7 \mathrm{~Hz}), 4.04(2 \mathrm{H}, \mathrm{s})$.

The second fraction was evaporated down and recrystallized from ethanol to give $0.8 \mathrm{~g}$ (yield $18.5 \%$ ) of VIf, $\mathrm{mp} 85-86^{\circ}$. Anal. Calcd. for $\mathrm{C}_{12} \mathrm{H}_{11} \mathrm{NOS}: \mathrm{C}, 66.33 ; \mathrm{H}, 5.10 ; \mathrm{N}, 6.45$. Found: $\mathrm{C}, 66.16 ; \mathrm{H}, 4.91 ; \mathrm{N}$, 6.22. NMR $\left(\mathrm{CDCl}_{3}\right) \mathrm{ppm}: 2.14-2.4(2 \mathrm{H}, \mathrm{m}), 3.1(2 \mathrm{H}, \mathrm{t}, J=7 \mathrm{~Hz}), 4.2(2 \mathrm{H}, \mathrm{t}, J=7 \mathrm{~Hz}), 6.5(1 \mathrm{H}, \mathrm{s}), 8.3-8.5$ $(1 \mathrm{H}, \mathrm{m})$.

$\mathbf{N}$ - $\gamma$-Mercaptopropylhomophthalimide (III)-A mixture of $1.8 \mathrm{~g}$ of I, $1.72 \mathrm{~g}$ of 3-amincpropanethiol hydrobromide and $0.82 \mathrm{~g}$ of $\mathrm{AcONa}$ in $20 \mathrm{ml}$ of $o$-dichlorobenzene was heated at $140-150^{\circ}$ for $2 \mathrm{hr}$ while removing water by azeotropic distillation. After cooling, the mixture was poured into ice-water and then extracted with $\mathrm{CHCl}_{3}$.

The extract was dried over $\mathrm{MgSO}_{4}$ and concentrated in vacuo. The residue obtained was passed through a column of silica gel and eluted with $\mathrm{CHCl}_{3}$ to give $1.3 \mathrm{~g}$ (yield $76 \%$ ) of III.

6-0xo-3,4-dihydro-2H,6H-1,3-thiazino[3,2-b]isoquinoline (IVf) - A mixture of $0.112 \mathrm{~g}$ of $\mathrm{N}$ - $\gamma$-mercaptopropylhomophthalimide and $0.172 \mathrm{~g}$ of $p$-toluenesulfonic acid in $4 \mathrm{ml}$ of $o$-dichlorobenzene was heated for $0.5 \mathrm{hr}$ at $120^{\circ}$. The reaction mixture was condensed in vacuo.

The residue was extracted with benzene and the extract was washed with water, dried over $\mathrm{MgSO}_{4}$ and then concentrated in vacuo. The residue was recrystallized from EtOH to yield $0.07 \mathrm{~g}$ (yield $68 \%$ ) of IVf.

Compound (IV): 6-0xo-3,4-dihydro-2H,6H-1,3-thiazino[3,2-b] isoquinoline (IVf) - A mixture of $3.6 \mathrm{~g}$ of I, $3.6 \mathrm{~g}$ of 3-aminopropanethiol hydrobromide and $1.64 \mathrm{~g}$ of AcONa in $20 \mathrm{ml}$ of $o$-dichlorobenzene was heated. The temperature of the reaction mixture was gradually increased and the resulting water was removed by azeotropir Histillation. After the water had been distilled off, the reaction temperature was kept at $140-150^{\circ}$ for $1 \mathrm{hr}$, then $3.6 \mathrm{~g}$ of $p$-toluenesulfonic acid was added at a temperature below $100^{\circ}$. After stirring for $1 \mathrm{hr}$, the reaction mixture was cooled at room temperature, poured into ice-water and extracted twice with $\mathrm{CHCl}_{3}$. The combined extract was washed with water, dried over $\mathrm{MgSO}_{4}$ and concentrated in vacuo. The residue was recrystallized from EtOH to yield $3.0 \mathrm{~g}$ of IVf (yield $69 \%$ ). Compounds IVb-IVy were prepared in the same manner.

Compound VI: 5-Oxo-2,3-dihydro-5H-oxazolo[3,2-b]isoquinoline (VIa)-_-A mixture of $3.6 \mathrm{~g}$ of I, $1.2 \mathrm{~g}$ of 2 -aminoethanol and $0.1 \mathrm{~g}$ of $p$-toluenesulfonic acid in $20 \mathrm{ml}$ of $o$-dichlorobenzene was heated at $150-160^{\circ}$ for $3 \mathrm{hr}$. The solvent was evaporated off $i n$ vacuo and the residue was recrystallized from AcOEt to give $2.2 \mathrm{~g}$ (yield $59.1 \%$ ) of VIa, mp $117-119^{\circ}$.

MS m/e: $187\left(\mathrm{M}^{+}\right)$. Anal. Calcd. for $\mathrm{C}_{11} \mathrm{H}_{9} \mathrm{NO}_{2}: \mathrm{C}, 70.58 ; \mathrm{H}, 4.85 ; \mathrm{N}, 7.48$. Found: C, 70.87; H. 4.80; $\mathrm{N}, 7.51$. NMR (CDCl $)$ ppm: $4.3(2 \mathrm{H}, \mathrm{t}, J=7 \mathrm{~Hz}), 4.64(2 \mathrm{H}, \mathrm{t}, J=7 \mathrm{~Hz}), 8.28(1 \mathrm{H}, \mathrm{d}, J=8 \mathrm{~Hz}), 5.86(1 \mathrm{H}, \mathrm{s})$. Compounds VIb-VId were prepared in the same manner.

Compound VII: 6-0xo-3,4-dihydro-2H,6H-1,3-thiazino[3,2-b] isoquinoline-1-oxide (VIIe)- $-\mathrm{H}_{2} \mathrm{O}_{2}(30 \%$, $0.57 \mathrm{ml}$ ) was added dropwise to a solution of $1.65 \mathrm{~g}$ of IVf in $10 \mathrm{ml}$ of $\mathrm{AcOH}$. The reaction mixture was stirred overnight at room temperature and then poured into ice-water. The resulting precipitate was collected and recrystallized from EtOH to give $0.9 \mathrm{~g}$ of VIIe, $\mathrm{mp} 132-133^{\circ}$.

MS mle: $233\left(\mathrm{M}^{+}\right)$. Anal. Calcd. for $\mathrm{C}_{12} \mathrm{H}_{11} \mathrm{NO}_{2} \mathrm{~S}: \mathrm{C}, 61.78 ; \mathrm{H}, 4.75 ; \mathrm{N}, 6.00$. Found: $\mathrm{C}, 61.85 ; \mathrm{H}$, $4.36 ; \mathrm{N}, 5.67$.

Compounds VIIa-VIIj were prepared in the same manner.

Compound VIII: 6-0xo-3,4-dihydro-2H,6H-1,3-thiazino[3,2-b]isoquinoline-1,1-dioxide (VIIId)—A solution of $1.5 \mathrm{~g}$ of IVf in $50 \mathrm{ml}$ of AcOH was treated with $1.58 \mathrm{ml}$ of $30 \% \mathrm{H}_{2} \mathrm{O}_{2}$ and the mixture was kept at

10) All melting points are uncorrected. IR spectra were run on a Hitachi 215 spectrometer. NMR spectra were recorded at $100 \mathrm{MHz}$ with a JEOL-MH100 or a JEOL-FX 100 machine using TMS as an internal standard. The following abbreviations are used: $\mathrm{s}=$ singlet, $\mathrm{d}=$ doublet, $\mathrm{t}=$ triplet, $\mathrm{m}=$ multiplet. Mass spectra were obtained using a Hitachi RMU-6MG double-focusing mass spectrometer. 
$70-80^{\circ}$ for $3 \mathrm{hr}$. The reaction mixture was cooled and the resulting precipitate was collected and recrystallized from AcOH to yield $1.17 \mathrm{~g}$ (yield $60 \%$ ) of VIIId, mp 206-208 .

MS m/e: $249\left(\mathrm{M}^{+}\right)$. Anal. Calcd. for $\mathrm{C}_{12} \mathrm{H}_{11} \mathrm{NO}_{3} \mathrm{~S} ; \mathrm{C}, 57.82 ; \mathrm{H}, 4.45 ; \mathrm{N}, 5.62$. Found: C, 57.69; $\mathrm{H}$, 4.32; N, 5.69. NMR (DMSO- $\left.d_{6}\right) \mathrm{ppm}: 2.3-2.6\left(2 \mathrm{H}, \mathrm{m}, \mathrm{C}_{3}-\mathrm{H}\right), 3.72\left(2 \mathrm{H}, \mathrm{t}, J=7 \mathrm{~Hz}, \mathrm{C}_{2}-\mathrm{H}\right), 4.27$ (2H, $\mathrm{t}$, $\left.J=7 \mathrm{~Hz}, \mathrm{C}_{4}-\mathrm{H}\right), 7.5\left(1 \mathrm{H}, \mathrm{s}, \mathrm{C}_{11}-\mathrm{H}\right)$. Compounds VIIIa-VIIIm were prepared in the same manner.

Compound XI: 1-Ethyl-2,3-dihydro-1H-imidazo[3,2-b](1,2) benzothiazine-5,5-dioxide (XIa)-A solution of $2.6 \mathrm{~g}$ of $\mathrm{N}$-ethylethylenediamine in $30 \mathrm{ml}$ of dry toluene was treated with $3.2 \mathrm{~g}$ of $o$-chlorosulfonyl benzylcyanide in $60 \mathrm{ml}$ of dry toluene at $-15^{\circ}$ dropwise. The reaction mixture was stirred at room temperature for 4 days. The solvent was evaporated off and the residue was washed with ether then recrystallized from $\mathrm{MeOH}$ to give $1.4 \mathrm{~g}$ (yield $35 \%$ ) of $\mathrm{XIa}, \mathrm{mp} 123-124^{\circ}$. MS m/e: $250\left(\mathrm{M}^{+}\right)$. Anal. Calcd. for $\mathrm{C}_{12} \mathrm{H}_{14} \mathrm{~N}_{2} \mathrm{O}_{2} \mathrm{~S}: \mathrm{C}_{\text {, }}$ $57.58 ; \mathrm{H}, 5.64 ; \mathrm{N}, 11.19$. Found: $\mathrm{C}, 57.34 ; \mathrm{H}, 5.66 ; \mathrm{N}, 11.08$. NMR $\left(\mathrm{CDCl}_{3}\right) \mathrm{ppm}: 1.2(3 \mathrm{H}, \mathrm{t}, J=7 \mathrm{~Hz})$, $3.2(2 \mathrm{H}, \mathrm{q}, J=7 \mathrm{~Hz}), 3.4(2 \mathrm{H}, \mathrm{t}, J=7 \mathrm{~Hz}), 4.0(2 \mathrm{H}, \mathrm{t}, J=7 \mathrm{~Hz}), 5.1(1 \mathrm{H}, \mathrm{s}), 7.0-7.4(3 \mathrm{H}, \mathrm{m}), 7.7-7.85$ $(1 \mathrm{H}, \mathrm{m})$. Compounds XIb and XIc were prepared in the same manner.

o-(N-Ethylaminoethylaminosulfonyl) benzylcyanide Hydrochloride (Xa) — $-O$-Chlorosulfonylbenzylcyanide $(0.43 \mathrm{~g})$ was added dropwise to a solution of $0.176 \mathrm{~g}$ of $\mathrm{N}$-ethylethylenediamine in $10 \mathrm{ml}$ of dry toluene at $-15^{\circ}$. The reaction mixture was stirred at room temperature for 4 days. The solvent was evaporated off in vacno and the residue was recrystallized from $\mathrm{MeOH}$ to give $0.35 \mathrm{~g}$ (yield $57.7 \%$ ) of Xa, $\mathrm{mp} 149-151^{\circ}$. MS mle: $267\left(\mathrm{M}^{+}\right)$. Anal. Calcd. for $\mathrm{C}_{12} \mathrm{H}_{18} \mathrm{ClN}_{3} \mathrm{O}_{2} \mathrm{~S}: \mathrm{C}, 47.44 ; \mathrm{H}, 5.97 ; \mathrm{N}, 13.83 ; \mathrm{Cl}, 11.67$. Found: $\mathrm{C}, 47.64$; $\mathrm{H}, 6.06 ; \mathrm{N}, 13.48 ; \mathrm{Cl}, 11.56$. IR $\nu_{\max }^{\mathrm{KBr}} \mathrm{cm}^{-1}: 2250(\mathrm{CN}) . \quad$ NMR (DMSO- $\left.d_{6}\right) \mathrm{ppm}: 1.2(3 \mathrm{H}, \mathrm{t}, J=7 \mathrm{~Hz}), 2.8-$ $3.2(6 \mathrm{H}, \mathrm{m}), 4.48(2 \mathrm{H}, \mathrm{s}), 7.6-7.8(3 \mathrm{H}, \mathrm{m}), 8.0(1 \mathrm{H}, \mathrm{d}, J=8 \mathrm{~Hz}), 8.64(1 \mathrm{H}$, broad) $9.0-9.4(1 \mathrm{H}$, broad).

1-Ethyl-2,3-dihydro-1H-imidazo[3,2-b](1,2) benzothiazine-5,5-dioxide (XIa)-Triethylamine (0.018 g) was added to a solution of $0.055 \mathrm{~g}$ of $\mathrm{Xa}$ in $1 \mathrm{ml}$ of $\mathrm{MeOH}$, and the reaction mixture was stirred at room temperature overnight. The solvent was evaporated off in vacuo and the residue was extracted with $\mathrm{CHCl}_{3}$. The extract was washed with water, dried over $\mathrm{MgSO}_{4}$ and concentrated in vacuo. The residue was recrystallized from $\mathrm{MeOH}$ to give $0.02 \mathrm{~g}$ (yield $44 \%$ ) of XIa.

Compound XIII : 2-Methyl-3-methylthioisoquinolone (XIIIa)—A mixture of $5.0 \mathrm{~g}$ of 3-chloro-2-methyl1-oxo-1,2-dihydroisoquinoline and $7.5 \mathrm{~g}$ of $20 \%$ sodium methylsulfide in $20 \mathrm{ml}$ of dimethylformamide was refluxed for $1.5 \mathrm{hr}$. The reaction mixture was cooled, poured into water and then extracted twice with AcOEt. The extract was washed with water and dried over $\mathrm{MgSO}_{4}$. The solvent was evaporated off in vacuo and the residue was recrystallized from cyclohexane to give $3.8 \mathrm{~g}$ (yield $71 \%$ ) of XIIIa, mp $83-85^{\circ}$. Anal. Calcd. for $\mathrm{C}_{11} \mathrm{H}_{11} \mathrm{NOS}: \mathrm{C}, 64.36 ; \mathrm{H}, 5.40 ; \mathrm{N}, 6.82$. Found: $\mathrm{C}, 64.49 ; \mathrm{H}, 5.17 ; \mathrm{N}, 6.91$. Compound XIIIb and XIIIc were prepared in the same manner.

The oxidation of XIIIa to give XIV and XV was performed as described for compounds VII and VIII.

Acknowledgement The authors wish to thank Dr. K. Takahashi for his advice. They are also indebted to the staff of the analytical section for microanalysis and spectral measurement, and to Dr. H. Maeno and T. Nomura for obtaining some of the biological data. 